DOI: 10.20472/IAC.2018.044.018

\title{
SIGURDUR GUDJONSSON
}

University of Akureyri, Iceland

\section{THE MICROFINANCE INDUSTRY}

\begin{abstract}
:
In this presentation the current stage of the microfinance industry will be described. The microfinance industry has increased drastically over the last few decades. It began as a handful of institutions in the late 1970's but is now a growing market with thousands of institutions. Most of the microfinance institutions are in the developing countries, particularly in India, Pakistan and Bangladesh. Recently, however, microfinance institutions are being established in the developed world. In addition in the presentation, a history of past failure of subsidized loans is explained. Different but important contributions from Stiglitz and Yunnus are accounted for. Finally, the microfinance industry's current state and potential future growth will be described.
\end{abstract}

\section{Keywords:}

Microfinance, poverty, loans

JEL Classification: M10, M14 